\title{
Political Interference in the Administration of Service Delivery in UMLALAZI Local Municipality of KwaZulu-Natal, South Africa
}

\author{
Sengiwakhile Mngomezulu \\ Department of Public Administration, University of Zululand, South Africa \\ mngomezulu26@gmail.com
}

\begin{abstract}
South African political interference in the administration of service delivery is a serious problem in many municipalities, where municipalities are experiencing serious challenges on how to deal with the interface between politicians and officials. Inappropriate political interference in administrative matters as well as strained relations between key political and administrative officials in the municipalities appears to be the order of the day. To understand the impact or consequences of political interference in the administration of service delivery, a case approach was adopted to evaluate the political interference in the administration of service delivery in uMlalazi Local Municipality of Kwazulu-Natal, South Africa. Participants comprises of Municipal Officials in the administrative side of the municipality, members of Ward Committee as well as other political parties expect the political party in power. The literature seeks to review the political-administrative interface, South African local government service delivery, conflation of legislative and executive roles of local government, reflection on local government performance and the critical issue of poor service delivery in South Africa.
\end{abstract}

Keywords: Political interference, Administration, Service delivery, Political party, Local government.

\section{Introduction}

The South African Constitution of 1996, section 40 (1) and (2) provides for a national system of local government. It charges local government with a developmental mandate and equips each municipality with a set of constitutionally protected powers. Provincial governments are tasked with the supervising and supporting municipalities but play a minor role with regards to regulating the local government systems. Municipal councils are democratically elected according to electoral system that combines constituency (ward) representation with proportional representation, a political system where the party with the highest number of votes forms the government. Politically, the local government scene is dominated by the African National Congress (ANC) which controls the lion's share of municipalities, though with some notable exceptions, particularly in the Western Cape Province where the City of Cape Town is controlled by the Democratic Alliance, the national opposition party (Visser, 2010). In terms of section 40 (1) of the Constitution of the Republic of South Africa (1996), government is constituted at national, provincial and local spheres, which are distinctive, interdependent and interrelated.

This establishes local authorities as a distinctive sphere, with a mandate to govern, to provide services (such as water, electricity, houses, roads and sanitation), and to promote social and economic development. In the 26 years of democracy South Africa has made some giant strides in certain key sectors of the economy like education and health, however, at local government level the equality and efficient delivery of basic services to people like water, sanitation, housing and electricity remains a huge challenge. In recent years there has been an escalation in the number of violent service delivery protests across the country with people frustrated at the slow pace of delivery and also at corrupt practices that have become endemic in some municipalities (Mdlongwa, 2014). Against this backdrop this work looks at some of the challenges within local government in order to understand how they hamper service delivery. This study seeks to evaluate the political interference in the administration of service delivery in uMlalazi Local Municipality of KwaZuluNatal, South Africa.

\section{Literature Review}

In research, Literature review is all about studying scholarly work or available body of knowledge that assist the researcher to see how other scholars have investigated the research problem. Dey (2005) stated that a literature review is a search for the published studies that are relevant to your topic to ensure that you have a grasp of what has been done in your area of intended study. This study reviews scholarly works based on 
Service Delivery in South Africa's local Municipalities, the effects of politics in service delivery of Local Municipality and legislation on Local Government Service Delivery. According to Swanson and Chermack (2013) the need to evaluate the effects of service delivery in general in South Africa cannot be overemphasized.

It is true that South Africa as a country is coming from a state of inequality and disparity in service delivery and will find it very difficult to address these disparities. It is, however, very important that various studies that have been done in terms of service delivery should in turn be evaluated so as to effect improvement on service delivery in general. Visser (2010) urges that it is, however, worth nothing that quality applied to managing service delivery in local government, while they seem appropriate to service organisations generally, these notions of quality do not necessarily meet all the criteria for quality in the provision of public services. This is precisely so because delivery of public services is a process based on broadly accepted formative and ethical values, as well as other prescribed guidelines. Ultimately, quality in local government cannot be isolated from those values, which relate to what is perceived as worthwhile in society. These values provide an ethically justifiable platform for determining and evaluating public service processes and outcomes, which might permeate the orthodox market-oriented notion of a quality culture in service delivery. McLennan \& Muslow (2009) notes that in order to redress these past imbalances, the ANC government was confronted with the challenge of transforming a racially and ethnically fragmented and unequal public service delivery system into one that would be able to meet the demands of a newly franchised citizenry for economic, social and political development.

Consequently, the legacies of the National Party (NP) government combined with widespread poor budgetary and financial management, a massive backlog in basic services and infrastructure, race and regional inequalities in provision and sometimes tense social relationships, tended to limit opportunities for social development for social development and expanded delivery. According to Masango (2002), before democratic dispensation in South Africa, apartheid deprived good public participation policy making and implementation in all three spheres of government. As a result of this, a majority of black South African were not afforded an opportunity to contribute to the process of developing and implementing policies that affected them particularly with regard to their participation. Simpson (2010) contends that the frequent, local government service delivery protests taking place in South Africa are almost a replica of what happened in most townships during the 1980's, when the disenfranchised majority of Africans took to the streets to protest against the imbalances of the NP government, in as far as the provision of services was concerned. It is generally argued that service delivery protests as experienced in South Africa under the ANC rule resembles the protest riots during the apartheid era. However, in this study the researcher argues that such analysis is more of a simplification of the political dynamics in the country (Simpson, 2010).

Under the ANC's rule, the mismatch between expectations, on the one hand, and limited skills, capacity and commitment on the other dented the dream of local democracy. Interestingly, the protests registered side-byside dissatisfaction with the quality and reach of service delivery, as well as the mechanisms of public representation of community interests (Booysen, 2011). According to Booysen (2011) the politics of service delivery in South Africa is both a top-down and bottom-up process. From top-down perspectives, the government determines policy frameworks and mechanisms of implementation, sets budgets and interprets mandates. Bottom-up perspectives illuminate the struggles of ordinary people for service delivery. Therefore, service recipients struggle to make their voices heard in the corridors of power that meander from local municipalities upwards to provincial premiers. To Southhall (2012) political appointments to senior executive management positions in South Africa compromised services and suggested that it was unlikely that existing levels of technical expertise would be maintained. In one way or another, the appointments of people without the relevant expertise compromised service delivery. Gumede (2013) argue that one problem in South Africa is that appointments to crucial posts in the civil service are still often based on political connections. This is also why it appears that the same senior civil servants rotate from one top job to another because only they can be politically trusted.

Theoretical Framework: Visser (2010) reported that, South African municipalities experience serious challenges in dealing with the interface between politicians and officials. Inappropriate political interference in administrative matters as well as strained relations between key political and administrative officials in the 
municipalities appears to be the order of the day. Oftentimes, the lack of a separation of powers between legislative and executive authority at local government level is blamed for this since legislative and executive authority are different. This means that the best people are not always recruited to manage crucial jobs. Since Gumede (2013), South hall (2012) and other scholars had pick pointed out that politicians have the effects on poor service delivery, therefore this study seeks to investigate the political interference in the administration of service delivery, on how do they affects the service delivery, why do they interfere in the administration, the impact of their interference, and what is the possible way forward with regard to the problem of undue political interference.

This contribution has attempted to draw the attention away from the conflation of legislative and executive authority in the municipal council while still recognising it as an important background. Local government, again, works in a more complex system. Since the Constitution designates the municipal council as the executive, it is essentially the employer of all municipal staff. Legislation has sought to separate council from the administration to some extent. The Municipal Systems Act mandates the municipal council to appoint senior managers (i.e. the municipal manager and managers that report to him or her, see s 82(1)(a) Municipal Structures Act and s 56 Municipal Systems Act), and further appointments are made by the administration itself. The Code of Conduct for Councillors includes a provision that prohibits councillors from interfering in the administration 9item 11 schedule 1 Systems Act). Taking a harder line of separation, the Municipal Finance Management Act (MFMA) has barred councillors from taking part in tender decisions (s 117 MFMA) and includes many provisions that seek to separate the council from the administration (RSA Constitution, 1996). Whilst the above explanation may provide a superficial explanation for many of the political interfering administration, the empirical evidence must be understood within a theoretical framework before a deeper interpretation of reality can be made.

Politics- Administration Dichotomy Theory: According to Spicer (2010), for more than a century, the politics-administration dichotomy has been one of the most disreputable issues in the field of public administration. The politics-administration dichotomy has had a strange history in public administration. It expands and contracts, rises and falls, but never to go away. Wilson (1887) stated that the field of administration is a field of business. It is removed from the hurry and strife of politics. Administration lies outside the proper sphere of politics. Administrative questions are not political questions. Although politics sets the tasks for administration, it should not be suffered to manipulate its offices. Wilson was concerned with both the corrupting and politicizing interference of party organisations in administrative affairs (King, 2001). He was critical of the way Congress handled core legislative functions. He stated that Congress policy making was haphazard and its oversight was weak. When Wilson suggested the clearer differentiation of politics and administration, he was seeking to strengthen and redirect the former while protecting the latter (Svara, 1998). Public administration is detailed and systematic execution of public law but the general laws are obviously outside of and above administration. The broad plans of governmental action are not administrative; the detained execution of such plans is administrative (Wilson, 1887).

The Classical Public Administration Theory: According to Wilson (1887) Public administration theory is divided into three branches. The three branches are, Classical Public Administration Theory, New Public Management Theory and Postmodern Public Administration Theory. Each of these three branches studies Public Administration from a different perspective. These theories explain the ways which administrators can understand and exercise their duties as a public administrator. Classical Public Administration Theory is often associated with Woodrow Wilson and Max Weber. Woodrow Wilson is known as "The Father of Public Administration", having written on "The Study of Administration" in 1887, in which he argued that a bureaucracy should be run like a business. Wilson promoted ideas like Merit-Based promotions, professionalism and a non-political system. Sympathy can lead to downfall in an administration; means there should be pragmatism in bureaucracy. The Classical Administration Theory will assist this study in explaining the relationship between politicians and administrators, and it will also help the researcher to differentiate the duties of Administrators and politicians to achieve the aims and objectives of the study under investigation. This theory will also help the researcher when analysing the data to support the arguments. 


\section{Research Methodology or Research Design}

Research methodology is a reflection of the entire approach for the research process. It is a strategy employed by the researcher to obtain answers to the research questions (Kerlinger, 1986). PoliticsAdministration Dichotomy theory will encapsulate this study on the grounds that it talks about politicaladministration since the researcher is evaluating the political interference in the administration of service delivery, it will also help the researcher to achieve the aim and objectives of the study when analysing the data to support the arguments. It is a procedural plan adopted by the researcher to provide valid objective and accurate answers to research questions and it entails data collection techniques and analysis as well as interpretation of findings. Qualitative research will be conducted because a problem needs to be explored. Through qualitative approach, participants are able to describe their perceptions on the effects of politics in service delivery.

Research Design: The researcher will employ the qualitative method because qualitative method allows the researcher to capture the experiences, perceptions and attitudes of the interviewees and it uses methods such as participant observation or case studies which will result in a narrative, descriptive account of a setting or practice. The nature of this study sought to explore a social phenomenon from multiple meanings. Creswell (2007) asserts that qualitative research uses methods such as participant observation or case studies which result in a narrative, descriptive account of a setting or practice. DeVos (1998) defined qualitative research as a multi-perspective approach utilizing different qualitative techniques and data collection methods to analyse social interaction, aimed at the meanings that the subjects attach to it, while Straus \& Corbin (1990) see qualitative research as any kind of research that produces findings not arrived at by means of statistical procedure or any means of qualification; it refers to research about a person life stories, behaviour, an organization's functioning, social movements or interactions and relationships. Since uMlalazi local municipality will be used as a case study, the researcher will make use of questionnaires so that the respondents will give the full details of their experiences about service political interference in uMlalazi local municipality.

Data Collection Instruments: Sekaran \& Bougie (2009) argue that data collecting instruments or methods are integral elements of the research design. There are several methods available in the research field, each with its own advantages and disadvantages. The researcher has chosen semi-structured interview to engage the Municipal officials and members of Ward Committee of the uMlalazi Local Municipality to get their views and opinions on the topic under investigation. In semi-structured interviewing, a guide is used, with questions and topics that must be covered. Semi-structured interviews are often used when the researcher wants to delve deeply into a topic and to understand thoroughly the answers provided (Sekaran \& Bougie, 2009). The researcher will focus on 7 municipal officials and 3 members of Ward Committee at uMlalazi Local Municipality because they are the key informants, they are in the administrative side of the municipality and service delivery is their daily basis job description or job specification, and they have relevant information about service delivery. Questionnaires shall be given to these people which, consist of open-ended as well as closed-ended questions that will give respondents a platform to answer freely and thus help the researcher to get more information on the topic at hand. Focus groups will be organized based on the types of positions in Municipal Officials and wards committee members. The researcher will also use tape recorders and field notes to strengthen the information from the respondents.

Target Population: A population is a group of individuals who have the same characteristics (Cresswell, 2012). According to Babbie (1992) "a population is that aggregation of elements from which the sample is actually selected. It is further explained as that group of people the researcher wants to draw conclusions". In this current study the target population is the Municipal officials and Ward Committee members of uMlalazi Local Municipality. The sample will also include 3 members of Ward Committee to represent the whole population of citizens of uMlalazi Local Municipality so that the researcher will know how does the political interference affects the service delivery. These Municipal Officials are administrative of the Municipality. These Municipal Officials are found at eShowe CBD, Gingindlovu CBD, Mtunzini CBD, and the citizens of the uMlalazi Local Municipality are found in the following locations: - Gingindlovu, Ncinyane, Salveshe, Mlalazi, 
Ntumeni, Mbongolwane and Wombane. The researcher has chosen Gingindlovu CBD and eShowe CBD so that he is able to generalize his study.

Sampling Procedures: This study will employ the purposive non-probability sampling technique to select participants (Municipal Officials and Citizens of the Municipality). According to Cooper and Schindler (2003, 103), "In purposive sampling the researcher selects people or sites who can best help to understand the phenomenon". According to Cresswell, (2012) "The inclusion of the participants will be based on the capacity of the participant to inform the research" (Quinlan et al, 2006). A distribution demonstrates that the city is arranged on the north-west bank of the territory of KwaZulu-Natal, nearly 160 KMS north-east of Durban. The N2 thruway navigates uMlalazi Local Municipality in a north-east course towards the Swaziland outskirt and south-west towards Durban. It viably shapes a division among Gingindlovu, Mtunzini and Eshowe. The R66 Provincial Main Road goes through Eshowe towards Dokodweni Tollgate. UMlalazi works as a locale hub and prevailing business focus in the uThungulu District. It comprises of an assortment of grouped and specially appointed settlements that are connected with a very much created system of streets framework. In this regards, the researcher will interview the 7 municipal officials from uMlalazi Local Municipality. These would be the Municipal Manager, Director Corporate Services, Chief Financial Officer, Director Community Services, Director Engineering Services, Director Protection Services and Director Planning and Development Department.

Data Analysis and Interpretation: Searching and arranging the interview transcript, field notes and other material that can be accumulated to increase understanding and to enable you to present what you have discovered to others (Creswell, 2012). As they are key informants on the topic under investigation because they deal directly with issues of political interference in their daily work. The Municipal Manager and Directors of the departments are chosen because politicians they use to interfere in the decisions they make on how to run the municipality or their departments. The transcribed data will be analysed by means of content thematic analysis and aided by thematic network analyses. Content thematic analysis is a flexible tool that involves the identifying of themes or patterns within data (Braun \& Clarke, 2006). Themes are defined as recurrent unifying concepts or statements about the subject of inquiry (Bladley, Curry, \& Devers, 2007). According to Attride-Stirling (2001), content thematic analyses can be successfully aided by and presented as thematic networks, which refer to web-like illustrations that summarise the basic, organising and global themes constituting a piece of text. Therefore, the researcher will read through the transcripts several times in order to understand the content of the transcripts and then sort the information by themes.

\section{Research Findings}

The results show that most of the respondents highlighted that the municipal administration is directed by the Municipal Manager since he is an accounting officer faced with the challenges of political interference in his duties where he is being forced to favour the ruling party (ANC) even when such act is unconstitutional. These findings concur with Visser's (2008) account that too many reports of fraud and corruption in municipalities point towards inappropriate interference exercised by political office-bearers. As the consequence of these findings, it is obvious that numerous municipal officials could be experiencing job burnout and occupational stress since the municipal political office holders appoints the municipal administrator. The respondents further indicated that political interference of the ruling party in administration of service pose a challenge of poor service delivery in the wards that are led by the opposition parties. Respondents cited the fact that "municipal manager face the challenge of political interference from the ruling party where the administrators are force to favour the ruling political party in the allocation of wards projects, demanding that developmental projects be allocated in the wards that are led by their councillors".

Furthermore, the result shows that when respondents were asked about how political interference affects service delivery in uMlalazi local municipality these factors emerged. The respondent highlighted that incompetent or unqualified employee's lead to poor service delivery. Respondents cited "to a certain extent it does affect service delivery, for example where incompetent person is employed may result to failure to satisfactorily his/her duties and the deployment of unqualified officials can also impact on service delivery." The ANC policy of cadre deployment which promotes that people must be employed based on their loyalty and long service in the organization, has impact in the service delivery because they deploy incompetent and 
unqualified employees who fail to perform their duties. Respondents further indicated that when the Integrated Development Plan (IDP) is compiled, projects are often allocated in favour of the ruling party members while the opposition is edged out in the process. Respondents further indicated that "basic services are used as political footballs to gain support to discredit either the ANC led municipality or the ward councillor and such incidents often leads to poor service delivery, as officials would rather point accusing fingers at each other than providing proper and quality service that will be effective and efficient to all wards."

This burning issue affects many South African citizens forcing many communities to protest while demanding for immediate or adequate service delivery or complaining about poor service delivery. When the respondents were asked about whether separation of legislative and executive roles helps in the administration of service delivery in the municipality, they clearly indicated that the local government system as a whole need to be reviewed as sometimes it does not lend itself to the meeting the needs of the people and service delivery may be skewed to favour the wards where the majority party is in control. Respondents further suggested that "separation of legislative and executive roles helps because it minimizes interference from other party. For example, section 117 of Municipal Finance Management Act prevents councillors from participating in bid committees or SCM processes. It does help as the legislative play oversight whilst the executive deals with almost day-to-day functioning of the municipality." The respondents also highlighted that it can help a lot because the municipal manager can perform his duties without any pressure or favour from a particular individual. One respondent commented "I think it can help because the municipal manager would be free to execute his duties without the fear of the political.

Parties, the skills of the employees will matter most and the political parties tend to mobilize for the employment of the people who do not have the skills and knowledge." It was also noted from the respondents that the legislative and executive roles is already separated in terms of the Municipal Structures Act and Municipal Systems Act, but interference is not written or documented as a results accounting officers find themselves in a huge dilemma of how to deal with the issue of political interference considering the fact that they are being employed by the very same politicians who are interfering in their duties. The political interference leads to poor performance of many municipalities which course the poor service delivery to the communities. The study reveals respondent's solutions through the opinions of the municipal officials, ward committee members and politicians on what they thought were possible solutions to the problem of political interference, which was the last item or question of the study. Respondents were asked what they thought needed to be done to reduce political interference in the administration of service delivery.

Respondents provided the following solutions:

- Allocation of projects must be procedurally fair.

- Municipal management must be employed in permanent contracts.

- Politicians must put people lives first before their political mandates or agenda.

- Cadre deployment systems must deploy competent and qualified people.

- Local government legislation must be reviewed and amended.

- Issues of party must not affect the state.

- Further certain positions must not be filled by political figures but rather by independents.

- Politicians must learn to differentiate between the state issues and political issues.

- Politicians must threat all wards equally irrespective of the political party governing the ward.

- Political office bearers must push the agenda of development not seeking self-interest.

\section{Conclusion and Recommendations}

Findings of the study, the critical challenge to the service delivery is political interference in the administration of service delivery in uMlalazi local municipality of Kwazulu-Natal, hence the poor service delivery to the citizens of this municipality, and other associated challenges that hinder the municipal administrative to perform their duties in manner that will promote effective and efficient standard of living of the communities in uMlalazi local municipality. This study has revealed the nature of the challenges of political interference in administrative duties and how these challenges have prevented the municipality 
from delivering quality of service to those that seek municipal attention on a day-to-day basis. Therefore, the researcher in this paper draw the following recommendations aim at assisting in reducing political interference in the administration of service delivery in uMlalazi local municipality of KwaZulu-Natal. The researcher believe that it will also give an insight to what can be done to reduce political interference in the administration of service delivery in South Africa as a whole:

- The findings of this paper suggest that the allocation of projects in wards of uMlalazi local municipality must be procedurally done in fairness to party concerned in order to promote effective and efficient quality service delivery to the community.

- In order for uMlalazi local municipality to reduce the issue of political interference, government must review the local government system which stipulates that management of municipalities must be employed on five years contract by the politicians.

- Furthermore, the uMlalazi local municipality politicians must learn to put people first before their political mandates or agendas, in other words politicians must learn to differentiate between the state issues and political issues.

- The findings of this paper also suggest the cadre deployment systems through politically disadvantage other political party must be done in a way to ensure that competent and qualified people are hired to manage certain positions rather than been filled with political apologists.

- The uMlalazi local municipality political parties must learn to have political tolerance and groom their members to be well equipped in order for them to fit in the municipal positions. In other words, all the political parties in the municipality for developmental purpose must for their political affiliations and work as a unit to enhance good service delivery.

- Government must review or re-look at the local government system to find ways to improve on the functioning of local government in order to promote the quality of service delivery to the community of uMlalazi local municipality and South Africa as a whole.

\section{Conclusion}

The issue of political interference in the administration of service delivery in local municipalities and government institutions as a whole is a serious problem which leads to poor service delivery. The researcher found that the opposition political parties that exist within the uMlalazi local municipality are concern about the political interference in the administration of service delivery in uMlalazi local municipality particularly, on tender awards, recruitment of employees and project allocating or distribution where by the politicians of the ruling or majority party in the municipality will force the municipal administration to squeeze the process so that the tender will be given to their friends or relatives, they also interfere on the employment processes whereby they want the administration to hire the incompetence candidates and projects are being allocated more in the wards that are led by the majority party which lead to poor service delivery in other wards that are led by opposition parties. This paper evaluates the political interference in the administration of service delivery in uMlalazi local municipality of KwaZulu-Natal, South Africa. This study has revealed the nature of the challenges of political interference in administrative duties and how these challenges have prevented.

The municipality from delivering quality of service to those that seek municipal attention on a day-to-day basis. The local government of a nation is its wealth. While the state has very good policies on paper towards ensuring legislative and executive roles or duties to promote effective and efficient of service delivery, the implementation on the ground is very poor. Accordingly, a number of possible solutions have been identified and suggested to reduce or eliminate these challenges. This study suggests that local government and uMlalazi local municipality should implement the above mentioned recommendations. This research was limited in the following ways; Research was conducted in uMlalazi Local Municipality Area only. Only the perceptions and opinions of uMlalazi Local Municipality' municipal officials, ward committee members and politicians were used to recommend solutions to the problem. Participants were scared to answer the questions, with most thinking that the researcher was an investigator or a member of the police or member of the majority party within the municipality. The researcher therefore had to go extra length to convince the people that the research was for academic purposes only. 


\section{References}

Atrride-Sterling, J. (2001). Thematic networks: an analytic tool for qualitative research. Qualitative Research, 1(3), 385-405.

Babbie, E., R. (1992). The Practice of Social Research (6th Ed): Belmont, Calif: Wadsworth Pub. Co.

Braun, V. \& Clarke, V. (2006). Using thematic analysis in psychology. Qualitative Research in Psychology, 3(2), 77-101.

Bradley, E., Currey, L., \& Devers, K. (2007). Qualitative data analysis for health services research: Developing taxonomy, themes and theory. Health Services Research, 42, 1758-1772.

Booysen, S. (2011). With the ballot and the brick: The politics of attaining serving delivery. Progress in Development Studies, 7(1):21-32.

Buhlungu, S., Daniel, J., Southhall, R. Lutchman, J. (2007): State of the Nation: South Africa 2007. Pretoria: HSRC Press.

Cooper, D., R. \& Shindler, P., S. (2003). Business Research Methods, 8th Edition, McGraw-Hill Irwin, Boston.

Cook, J. B. (2014). Bureaucracy and Self-Government: Reconsidering the Role of public administration in American Politics (2 ${ }^{\text {nd }}$ Ed). Johns Hopkins University Press.

Creswell, W. J. \& Clark, L.P.V. (2007). Designing and conducting mixed methods research. Sage Publications.

Cresswell, J. W. (2012). Qualitative, Quantitative, and Mixed Methods Approaches. 3rd Edition. Thousand Oaks: CA: Sage

De Visser, J. W. \& Akintan, O. (2008). Institutional Tensions between Municipal Chairpersons and Executives Speaking of Mayor Conflicts? Community Law Centre.

De Vos, A. S. (1998). Research at grass roots - for the social sciences and human service professions 4/e.

Dey, I. (2005). Qualitative data analysis. Taylor and Francis Group: Routledge, London

Gumede, W. (2013). Delivering the democratic state in South Africa. Johannesburg: Wits University Press,

Kerlinger, F. N. (1986). Foundations of Behavioural Research, 3rd Edition, Holt, Rinehart and Winston, New York.

King, D. (2001). Complete Works of Robert and James Adam and Unbuilt Adam. Architectural Press.

Masango, R. (2002). Public Participation: A Critical Ingredient of Good Governance. Politica, 21(2), 52-65.

Mdlongwa, E. T. (2014). Local government at the heart of poor service delivery. Rhodes Journalism Review, 34: 39.

Mc Lennan, A. \& Munslow, B. (2009). The Politics of Service Delivery. Johannesburg: Wits University Press

Quinlan, N. J., Basa, M., \& Lastiwka, M. (2006). Truncation error in mesh-free particle methods. International Journal for Numerical Methods in Engineering, 66(13), 2064-2085.

Sekaran, U. \& Bougie, R. (2009). Research Methods for Business: A skill Building approach, 5th Edition. Wiley \& Sons: West Sussex.

Simpson, A. (2010). Analysts' Use of Non-financial Information Disclosures. Contemporary Accounting Research, 27(1), Available at SSRN: https://ssrn.com/abstract=1133182.

Strauss, A. L., \& Corbin, J. (1990). Basics of Qualitative Research: Grounded Theory Procedures and Techniques. Newbury Park, CA: Sage Publications.

Swanson, A. R. \& Chermack, J. T. (2013). Theory Building in Applied Disciplines. San Francisco, CA: BerrettKoehler Publishers.

Spicer, W. M. (2010). In Defense of Politics in Public Administration: A Value Pluralist Perspective. University Alabama Press.

Stillman, R. J. (1991). Preface to public administration: A search for themes and direction. New York: St. Martin's.

Svara, J. H. (1998). The Politics-Administration Dichotomy Model as Aberration. Public Administration Review. 58(1), 51-58.

Wilson, W. (1887). The study of administration. Political Science Quarterly, 2, 197-222. 